\title{
Impact of Internal Control in Enterprises Founded by Local Self-Government Units: The Case of Republic of Serbia
}

\author{
Milan Radovic ${ }^{1}$, Jelena Vitomir ${ }^{2}$, Slobodan Popovic ${ }^{3}$ \\ ${ }^{1}$ University of East Sarajevo \\ Alekse Santica No. 3, 71420 Pale, Bosnia and Herzegovina \\ E-mail.knowledgemilan@gmail.com \\ ${ }^{2}$ University of Megatrend in Belgrade \\ Bulevar Marsala Tolbuhina No. 8, 11070 New Belgrade, Republic of Serbia \\ E-mail.jelena.vitomir1@gmail.com \\ ${ }^{3}$ Economic Academy \\ Cvecarska No. 2, 21000 Novi Sad, Republic of Serbia \\ E-mail.slobodan.popovic49@gmail.com*Correspondent author \\ cross $^{\text {ref }}$ http://dx.doi.org/10.5755/j01.ee.32.1.23243
}

In the countries in transition, like the Republic of Serbia, system innovations are being introduced, such as the implementation of internal controls in enterprises. The authors of the paper formulated a research question which is if the introduction of internal controls could have an impact on the improvement of governance in public utility enterprises founded by the units of local self government. The main goal of the research was to identify possible improvement in corporate operations measured by an increase in revenues made by public utility enterprises following the implementation of internal controls. In addition to that, the secondary goal of the authors was to determine differences in operating efficiency between public utility enterprises and the so called other enterprises that put in place internal controls in their current operations. Further on, the authors of this paper wanted to find out which type of internal controls in place in public utility enterprises and other enterprises enabled best performance. The usefulness of the study is visible in the presented results of the research. Specifically, they indicate significant differences between public utility enterprises and other enterprises, both in terms of implementation of internal controls and in their performance, which was proven in 2018. In addition to that, performance of public utility enterprises founded by local self-government units is found to be better than that of the so called other enterprises after the introduction of internal controls.

Keywords: Internal Control; Company; Association; Enterprises; EU.

\section{Introduction}

Modern corporate governance predominantly relies on financial reporting, as pointed out in a great number of papers (Tett, 2019; Toms, 2019). Besides, an improvement of financial reporting requires a certain level of audit (Coffee, 2019; Izza, 2019), which is accepted by the authors of the paper as a research assumption, against directing our research toward answers to questions on establishing control mechanisms in enterprises, or more precisely, toward the introduction of internal controls in public utility enterprises founded by local self-government units. In conducting the presented research, the authors of the paper used the stated positions on the improvement of governance in the public sector (Wynen \& Verhoest 2016; Reginato et al.; 2016; Fatima et al., 2019), but it should be noted that positions of authors who focused their research on governance in nonpublic sector were also taken into account (Blair, 2017), as well as of those authors who published papers on governance viewing it from a somewhat broader aspect than the said financial management (Lewis \& Young, 2019).

Introduction of internal controls into enterprises in the Republic of Serbia is gaining in importance, in particular after opening Chapter 32 (in December 2015) by the
Republic of Serbia within its EU accession process. That resulted in the harmonization of work organization in enterprises with the EU norms of conduct and doing business. Internal control introduction into public enterprises is of great importance as those enterprises run business using budgetary funds collected from taxpayers. Furthermore internal controls are place enables top management to make valid business decisions.

The research was conducted in a country in transition with a socialist economic background inherited from the former state of Yugoslavia. Republic of Serbia aspires to share EU experience and its best practice. The authors of the paper intended to point out the importance of introduction of internal controls, in particular in public utilities. With internal controls in place, transparency of corporate operations increases on the one hand, whereas, on the other hand, it might contribute to a better performance of public utility enterprises in the Republic of Serbia.

Financial control development is an obligation the Republic of Serbia undertook on its way to the EU membership. The purpose of internal control implementation could be a more adequate use of budgetary funds, fund funds, in particular those from the EU funds. This way it is shown that implementation of internal controls of enterprise 
operations is becoming one of stability pillars which can result in an improved performance of the public sector, particularly due to the way in which financial control is conducted in public utility enterprises founded by the local self-government units.

Due to the above stated the authors formulated the following research question and set a goal. The issue to deal with in the research was the importance of the introduction of internal controls in public utility enterprises founded by the local self-government units. On the basis of this question, the set goal of the research was to increase the understanding of the importance of implementation of internal controls in order to achieve possible benefits measurable as an increase in operating revenue in public utility enterprises with internal controls in place.

On the basis of the stated, the authors formulated the research goals. The first goal was to determine a possible improvement in operating results in public utility enterprises founded by the local self-government units following the implementation of internal controls. The other aim of the authors was the analysis of the presented revenues following the implementation of internal controls in the two said types of enterprises - public utility enterprises and the so called "other enterprises". The third goal of the authors was a more precise identification of the forms of internal controls in place in those enterprises. The fourth aim was to determine those forms of internal controls that enable optimum results in public utility enterprises founded by the local selfgovernment units.

As to the structure, the study consists of two parts. Part one deals with the initial research conducted by the authors. The researched commenced using SWOT analysis relating to the implementation of internal controls in the operations of public utility enterprises founded by the local selfgovernment units. The authors pointed out four important issues relating to the implementation of internal controls and they are: available options, weaknesses, opportunities and threats. In part two the processed results of a representative survey are presented. The survey comprised 172 enterprises, making $25 \%$ of the total number of enterprises founded by the local self-government units in the Republic of Serbia. The survey was conducted in 2018. Following that, the authors compared the obtained results, i.e. observed the total revenue of enterprises in the year preceding the implementation of internal controls and the amounts of total revenue following the introduction of internal controls by examining the financial statements (annual financial statements filed with competent state bodies) of the two types of enterprises under review. Internal control research comprised three forms of internal controls, i.e. fully implemented internal controls partially implemented internal controls and internal controls in the process of implementation (implying only the existence of the adopted company deeds relating to internal controls).

A survey questionnaire was completed by enterprise top management members, i.e. financial and accounting sector managers. The authors guaranteed confidentiality as to data on enterprises involved in the survey. In addition to that, we obtained a permission to publish the research results for scientific purposes without specifying names of enterprises. Consequently, a standard statistical and correlation analysis was made.
IBM SPSS statistical software was used for data processing. A descriptive statistics gave an initial insight into data, more precisely; representation frequencies of the variables used in the sample were calculated. Following that the authors determined non-existence of extreme values and found no data were missing. Furthermore, in order to gain a further insight into mutual relations of the used indicators, Crosstabs option was applied, i.e. frequency crossing to see the inter-relations of variables. As the variables were categorical, i.e. nominal, a corresponding correlation analysis was made in order to find answers to the set hypotheses. The contingency coefficient met the requirements of nominal level of measurement and the authors used it in further statistical processing.

The research was completed in quarter 1 of 2019, and the conclusions that may be drawn from the obtained results relate to 2018. The expected results show correlations between the types of enterprises included in the survey and total revenue, forms of the implemented internal controls. The authors point out that the expected results relating to the implementation of internal controls might be used by a great number of top management members, in particular in public enterprises, as guidelines in future business decision making, i.e. internal controls in place may yield practical benefits in real enterprise operations.

\section{Theoretical Background}

The management processes largely depend on the impact of the economic and political environment. The processes of globalization (as a phenomenon), for most of mankind, begin to work after the First World War. In the second half of the 19 th century, in most Western countries, there was a demand for a continuous reduction of costs, as an imperative, for the management of the economy. At that time, the dominant ideology is the acceptance of liberalism as the direction necessary for the growth and development of the economy. This trend is present in all activities, and the acceptance of the western concept of economic management is also flowing to the countries of Asia, Latin America and the transitional countries. Gradually, the concept of liberalism is changing, and a neo-liberalism system is formed that combines concepts: global market, acceptance of international financial organizations, multilateral communication and new systems of globalization.

The globalization of the society can be used for the advancement of human society, especially if the negativity of neoliberals, especially in relation to transitional countries (privatization, stabilization, etc.) is rejected.

These processes are indirectly imposed and require the top management to find ways to improve the management of the entrusted enterprise. One of the possible ways to improve the work is to introduce internal controls into the management and decision-making processes of the company.

Continuous management of public enterprises (Williams, 2010) requires a comprehensive analysis (Popovic, 2014) of business results (Pernek, 2001; Vranjes, 2011; Majstorovic et al., 2015; Mijic \& Popovic 2016), in order for top management to deliver valid business decisions by which it could improve the business of the company. The stability of the functioning of management depends on many factors, although several authors point out 
the importance of fiscal impacts on the company's operations (Brezovnik \& Oplotnik, 2003; Kukovic et al., 2016; Alibegovic et al., 2018).

The non-indivisible part of the management of the company represents the correct evaluation (Svoboda, 2007; Liu, 2010; Horton et al., 2011; Drazic-Lutilsky et al., 2012; Durocher \& Gendron, 2014; Liang \& Riedl, 2014; Popovic et al., 2015; ) parts of the company and all other factors related to the rational management of the management. Essential such an approach requires the adoption of longterm business decisions at the level of the entire economy (Perry \& Shivdasani, 2005; Davis \& Nicholson-Crotty, 2016), to enable a realistic development of the economy of a state (Topcu \& Serap Coban, 2017).

In addition to the above, it should be noted that the observed management should be considered as a process in which the implementation of the standardization process plays an important role (Marston \& Shrives, 1991; Ege, 2015; Malone et al., 2016; Popovic et al., 2017), especially in the public sector (Santos \& Dias, 2014), which should be considered as part of observing the functioning of the region (Scalera, 2016).

Numerous authors emphasize the importance of the functioning of internal control mechanisms through which top management can empower high-quality business decisions.

One of the ways to strengthen top management's decisions is to apply internal controls in the functioning of public enterprises, which are highlighted by numerous authors (Blankley et al., 2012; Pridgen \& Wang, 2012; Cheng et al., 2013; Ruhnke \& Schmidt, 2014; Renyu \& Lee, 2016; Chen et al., 2017; Jingwen, 2017; Mengmeng, 2017; Chen, 2019).

Published positions of the above stated authors were used in this study against an emphasis that another important view of an author was used (Wyatt, 2004) who pointed out the importance of "professionalism" as a factor of valid corporate governance.

Except this view, the authors of the paper also used general views of the authors who dealt with corporate governance as a comprehensive system continuously linked to compatible mechanisms, such as internal control, internal audit and other mechanisms that can be used for improvement of corporate governance mechanism (Williams \& Rodgers, 1995; Wang et al., 2014; Wang, 2016; Corona et al., 2019).

\section{Research Methodology}

\section{Research Hypotheses}

In order to ensure drawing valid conclusions on the implementation of internal controls in enterprises, the authors set four hypotheses:

H1: There is no relationship between the two types of enterprises (public utility enterprises founded by the local self-government units and the so called "other enterprises") and total revenue made by those enterprises.

H2: There is no relationship between the form of the implemented internal controls in the two types of enterprises included in the survey.

H3: There is no relationship between the form of the implemented internal controls and total revenue of enterprises included in the survey.

H4: There is no relationship between the form of the implemented internal controls and total revenue made in the two forms of enterprises under observation.

\section{Results of the Analysis}

\section{SWOT Analysis of the Position of Public Utility Enterprises}

The research presented in this paper consists of two parts. In the first part the authors, using SWOT analysis, presented basics of recognition of positive and negative factors relating to the implementation of internal controls in public utility enterprises founded by the local selfgovernment units (Table 1).

SWOT Analysis of the Situation for Public Enterprises Established by Local self-Government Units that Implement the Internal Control at the end of 2018 in the Republic of Serbia

\begin{tabular}{|c|c|}
\hline Available options & Weaknesses \\
\hline $\begin{array}{l}\text { - The existence of a signed Chapter } 32 \text { with the EU on financial } \\
\text { control in the public sector, } \\
\text { - The existence of positive attitudes of internal audit introduced } \\
\text { in the public sector, } \\
\text { - adopted internal audit procedures are compatible with internal } \\
\text { control procedures, } \\
\text { - Many years of tradition in applying audit procedures in the } \\
\text { public sector }\end{array}$ & $\begin{array}{l}\text { - Lack of complete information on the importance of full } \\
\text { implementation of internal control in the public sector, } \\
\text { - Lack of interest of local self-government units to significantly } \\
\text { increase the operational reliability of companies, } \\
\text { - Insufficient interest of companies that have established local self- } \\
\text { government units for internal control in terms of essential financial } \\
\text { reporting to the founder, } \\
\text { - The frequent change of the top management appointed by the local } \\
\text { self-government causes discontinuity in the performance of } \\
\text { commenced tasks in the introduction, control and implementation } \\
\text { of internal control recommendations in enterprises }\end{array}$ \\
\hline Chances & Threats \\
\hline $\begin{array}{l}\text { - Increase in commitments based on signed pre-accession } \\
\text { chapters with the EU, } \\
\text { - Increasing the safety of top management that has } \\
\text { implemented internal control in the companies it manages, } \\
\text { - Increasing the security of financial reporting to local } \\
\text { government and state authorities, }\end{array}$ & $\begin{array}{l}\text { - Insufficient sanctioning of companies established by local self- } \\
\text { government in terms of poor financial reporting, } \\
\text { - Insufficient sanctioning of public utility companies established by } \\
\text { local self-government in terms of poor implementation of business } \\
\text { programs }\end{array}$ \\
\hline
\end{tabular}


Milan Radovic, Jelena Vitomir, Slobodan Popovic. Impact of Internal Control in Enterprises Founded by Local ...

\begin{tabular}{|l|l|}
\hline \multicolumn{1}{|c|}{ Chances } & Threats \\
\hline - Facilitates public-private investment activities in the public & \\
sector, & \\
- Internal control contributes to the increase in the level of local \\
government investment in the primary enterprises due to the \\
increased security of investment and the return of funds into \\
the budget based on the generated profit of the company
\end{tabular}

\section{Source: authors' calculation}

\section{Results of basic Research}

In the second part of the paper the authors presented results of the survey questionnaire completed by top managers, i.e. questions on the implementation of internal controls in 172 enterprises answered by them. The authors compared the two types of enterprises on the basis of the three forms implemented of internal controls and also compared their operating results on the basis of total revenue of enterprises included in the survey.

The research focused on two types of public enterprises, namely public utility enterprises or enterprises providing public services: water supply, heating, community cleaning, maintenance of residential buildings, green areas etc., and the other type of enterprises termed "other enterprises", carrying out other activities, such as: organization of sports events, urban development within the domain of local selfgovernment, public transport and other activities of importance for local self government units.

Based on the setting $\mathrm{H}$ : 1 , the authors gave an overview of frequency acceleration, namely: two forms of observed enterprises founded by local self-government units and the total revenue generated by these companies (Table 2), after which the authors presented the results of correlation of values coefficient and level of significance (Table 3).

Cross-Frequency Representation, Shape Business and Revenue Generated

\begin{tabular}{|c|l|c|c|c|c|c|}
\hline \multicolumn{2}{|c|}{} & \multicolumn{3}{|c|}{ Total revenue } & \multirow{2}{*}{ Total } \\
\cline { 3 - 6 } \multicolumn{2}{|c|}{} & $\mathbf{1}$ & $\mathbf{2}$ & $\mathbf{3}$ & $\mathbf{4}$ & \\
\hline \multirow{2}{*}{ Type of company } & Public utility companies & 0 & 39 & 45 & 32 & 116 \\
\cline { 2 - 6 } & Other companies & 25 & 15 & 16 & 0 & 56 \\
\hline \multicolumn{2}{|c|}{ Total } & & 25 & 54 & 61 & 172 \\
\hline
\end{tabular}

Source: authors' calculation

On the basis of the values of crossed frequencies (type of enterprise and total revenue) given in Table 1, it is clearly seen that in enterprises that introduced internal controls there is an increase in total revenue and that the increase in total revenue is greater in public utility enterprises founded by the local self-government units.

Table 3

The Correlation between the Correlation between Type of Enterprise and Total Revenue

\begin{tabular}{|c|c|c|c|}
\hline & & Value & Approx. Sig. \\
\hline Nominal by Nominal & Contingency Coefficient & .535 & .000 \\
\hline \multicolumn{2}{|c|}{$\mathrm{N}$ of Valid Cases } & 172 & \\
\hline
\end{tabular}

Source: authors' calculation

On the basis of values presented in Table 3, it can be seen that the statistical significance of the assumed hypothesis is verified with the correlation coefficient, i.e. the results show that the significance level is $\mathrm{p}=.000$, and that there is a significant correlation between an increase in

total revenue and the type of enterprise as the correlation coefficient is 0.53 .

Having set $\mathrm{H}: 2$ the authors present the frequency relating to the forms of implemented internal controls and type of enterprises included in the survey (Table 4), and the correlation of the stated values are shown in Table 5 .

Table 4

Frequency Visibility of Enterprise Type and Form of Internal Control

\begin{tabular}{|c|c|c|c|c|c|c|}
\hline & & \multicolumn{4}{|c|}{ Form of internal control } & \multirow[t]{2}{*}{ Tota } \\
\hline & & 1 & 2 & 3 & 4 & \\
\hline \multirow{3}{*}{ Type of company } & Completely & 0 & 0 & 16 & 32 & 48 \\
\hline & Partially & 0 & 15 & 45 & 0 & 60 \\
\hline & In the procedure of & 25 & 39 & 0 & 0 & 64 \\
\hline Total & & 25 & 54 & 61 & 32 & 172 \\
\hline
\end{tabular}

Source: authors' calculation

On the basis of what is presented (Table 4), the analysed frequency of the type of enterprise and the form of the implemented internal controls does not result in any trend of common changes in the variables used. 
View Correlation Coefficient, Types of Enterprises and Forms of Internal Control

\begin{tabular}{|l|c|c|c|}
\hline \multicolumn{2}{|c|}{ Approx. Sig. } \\
\hline Nominal by Nominal & Contingency Coefficient & Value & .127 \\
\hline N of Valid Cases & 172 & \\
\hline
\end{tabular}

Source: authors' calculation

On the basis of the presented table (Table 5), the correlation value of the type of enterprise and the form of implemented internal controls is low ( $p>.05$ ), i.e. the relationship between them is not in correlation.
On the basis of $\mathrm{H}: 3$ the authors presented frequencies of the form of internal controls and total revenue of the enterprises included in the survey (Table 4) with the presentation of correlation coefficient (Table 6).

Table 6

Frequency of the Visibility of the Type of Enterprise and form of Internal Controls

\begin{tabular}{|c|c|c|c|c|c|c|}
\hline & \multicolumn{4}{|c|}{ Total revenue } & \multirow[b]{2}{*}{ Total } \\
\hline & & 1 & 2 & 3 & 4 & \\
\hline \multirow{3}{*}{ Form of internal control } & Completely & 0 & 0 & 16 & 32 & 48 \\
\hline & Partially & 0 & 15 & 45 & 0 & 60 \\
\hline & In the procedure of & 25 & 39 & 0 & 0 & 64 \\
\hline Total & & 25 & 54 & 61 & 32 & 172 \\
\hline
\end{tabular}

Source: authors' calculation

Based on the table view (Table 6) With regard to the frequency of the degree of introduction of internal control and realized revenues, it is noticeable that more revenues are

generated by enterprises with completely or at least partially introduced degree of internal control.

Table 7

Indicative Coefficient of Correlation, when Crossings are Realized Revenues and form of Introduced Internal Control

\begin{tabular}{|c|c|c|c|}
\hline & & Value & Approx. Sig. \\
\hline Nominal by Nominal & Contingency Coefficient & .740 & .000 \\
\hline $\mathrm{N}$ of Valid Cases & & 172 & \\
\hline
\end{tabular}

Source: authors' calculation

On the basis of the values presented in Table 4 and relating to the introduced internal controls and increase in total revenue, it is noticeable that enterprises with fully or at least partially introduced internal controls have higher total revenue.
On the basis of the values presented in the table (Table 6 ), the authors confirm the hypothesis that there is a relationship between the total revenue and the form of implemented internal controls in those enterprises $(p=.00)$, which is confirmed by the obtained coefficient. This affirms the view that there is a strong relationship, i.e. $\mathrm{C}=.74$.

Table 8

The Frequency of Frequencies Crossing the form of Introduced Internal Control and Realized Revenues in Relation to the Type of Companies Surveyed

\begin{tabular}{|c|c|c|c|c|c|c|c|}
\hline & \multicolumn{4}{|c|}{ Total revenue } & \multirow{2}{*}{ Total } \\
\hline & & & 1 & 2 & 3 & 4 & \\
\hline \multirow{4}{*}{$\begin{array}{l}\text { Public utility } \\
\text { companies }\end{array}$} & \multirow{3}{*}{$\begin{array}{l}\text { Form of internal } \\
\text { control }\end{array}$} & Completely & & 0 & 0 & 32 & 32 \\
\hline & & Partially & & 0 & 45 & 0 & 45 \\
\hline & & In the procedure of & & 39 & 0 & 0 & 39 \\
\hline & Total & & & 39 & 45 & 32 & 116 \\
\hline \multirow{4}{*}{$\begin{array}{l}\text { Other } \\
\text { companies }\end{array}$} & \multirow{3}{*}{$\begin{array}{l}\text { Form of internal } \\
\text { control }\end{array}$} & Completely & 0 & 0 & 16 & & 16 \\
\hline & & Partially & 0 & 15 & 0 & & 15 \\
\hline & & In the procedure of & 26 & 0 & 0 & & 25 \\
\hline & Total & & 25 & 15 & 16 & & 56 \\
\hline
\end{tabular}

Source: authors' calculation

On the basis of $\mathrm{H}: 4$, the authors presented results that indicate that there is no statistically significant relationship between the introduced form of internal controls and total revenue on the one, and the type of enterprises included in the survey on the other hand (Table 7), whereas the obtained correlation coefficients for the given values are presented in Table 8. 
Presentation of the Coefficient of Correlation of the Forms of Introduced Internal Control and Realized Revenues in Relation to the Type of Enterprise

\begin{tabular}{|l|c|c|c|c|}
\hline Public utility companies & Value & Approx. Sig. \\
\hline $\begin{array}{l}\text { Public utility } \\
\text { companies }\end{array}$ & $\begin{array}{c}\text { Nominal by } \\
\text { Nominal }\end{array}$ & Contingency Coefficient & .816 & .000 \\
\cline { 2 - 5 } & \multicolumn{2}{|c|}{ N of Valid Cases } & 116 & .000 \\
\hline \multirow{2}{*}{$\begin{array}{l}\text { Other } \\
\text { Nompanies }\end{array}$} & \begin{tabular}{c} 
Nominal by \\
\cline { 2 - 4 }
\end{tabular} & Contingency Coefficient & .816 & 56 \\
\hline
\end{tabular}

On the basis of values presented in (Table 7) relating to the form of introduced internal controls and total revenue on the one, and the type of enterprise on the other hand, the lowest increase in revenues is that of public utility enterprises founded by the local self-government units, whereas there is no increase in total revenue in the so called „other enterprises”.

On the basis of the values presented in the table (Table 8), the authors point out that there is a statistically significant relationship between the form of internal controls and total revenue when compared to the two said types of enterprises included in the survey $(p=.00)$, as the coefficient is 0,81 .

\section{Discussion}

The obtained results are divided into five parts in the study. They could be useful to experts in the respective field and top management of companies as an indicator to be considered in their future decision making process when making valid business decisions aimed at improvement of corporate governance. The emphasis of the significance of introduction of internal controls in corporate governance is the primary contribution of the authors of this paper based on the research done and presented by them.

In the first part, the results of the SWOT analysis (Table 1) are presented. The analysis relates to public utility enterprises founded by the local self-government units. Overcoming the spotted weaknesses could bring benefits on the short run, which is of great importance for the enterprises under review.

Part two deals with the research results shown in Table 2 and Table 3. The results indicate growth in total revenue of enterprises which introduced internal controls. The growth in total revenue is higher in public utility enterprises founded by the local self-government units (116) than in "other enterprises" (56) out of 172 enterprises included in the survey. On the basis of $\mathrm{H} 1$, that there is no relationship between the two types of enterprises and total revenue made by those enterprises, the authors correlated the two types of enterprises and 2018 total revenue. According to the obtained results $\mathrm{H}: 1$ is rejected as the obtained values are statistically significant $(\mathrm{p}=.000)$, against a significant correlation between the total revenue and the type of enterprise with internal controls in place, as the correlation coefficient value is 0,53 .

Part three comprises research results (Table 4 and Table 5) of the relationship between the type of enterprise and the form of introduced internal controls as set in $\mathrm{H} 2$. On the basis of the obtained results (Table 5), the authors state that
$\mathrm{H}: 2$ is accepted as there is statistically significant relationship between the type of enterprise and the form of internal controls in enterprises under review, i. e. the obtained correlation coefficient is ( $p>.05)$.

Part four deals with $\mathrm{H} 3$, that there is no relationship between the form of the implemented internal controls and total revenue of enterprises included in the survey. The results of the survey are presented (Table 4 and Table 6) and indicate a trend of higher total revenue posted by enterprises with fully or partially implemented internal controls. According to the obtained results, $\mathrm{H} 3$ is rejected as the value is $(\mathrm{p}=.00)$, with coefficient, $\mathrm{C}=.74$, and with the existence of a statistically significant relationship between the form of implemented internal controls and total revenue $(\mathrm{p}=.000)$ of the enterprises included in the survey. The authors point out that public utility enterprises founded by the local selfgovernment units with fully implemented internal controls made higher revenues.

Part five deals with $\mathrm{H} 4$, that there is no relationship between the form of the implemented internal controls and total revenues made and the type of enterprise. The results of the survey are presented in (Table 7 and Table 8). The results indicate that there is a small increase in total revenue of public utility enterprises founded by the local selfgovernment units, whereas there is no growth in total revenue in the so called "other enterprises". According to that, $\mathrm{H} 4$ is rejected as it is evident that there is a statistically significant relationship between the form of the implemented internal controls and total revenue made on the one, and the type of enterprise on the other hand $(\mathrm{p}=.00)$, as they obtained coefficient value is 0,81 .

\section{Conclusion}

Assumptions given at the beginning of the paper expand the existing theoretic approaches, emphasizing the necessity of using internal controls in enterprises. Empirical evidence is added to previously stated assumptions in the paper and presented by the authors. Therefore, this research offers a new view of practical implementation of internal controls in the two types of enterprises.

This paper gives an overview of possible improvements in corporate governance by top management through the implementation of internal controls in enterprises, predominantly in public utility enterprises founded by the local self-government units. The results presented as benefits (increase in the total revenue of enterprises) resulting from the implementation of internal controls could be upgraded or extended in future research activities. Besides, the authors find that there is an actual lagging of 
the so called "other enterprises" with regard to the implementation of internal controls in them.

The authors point out that there is a difference between operating results of the two types of enterprises that implemented one of the three forms of internal controls. Some future research might help identify from of internal controls convenient to be implemented in the two types of enterprises.

Practical implications of the study might be of importance for the top management of both forms of enterprises with internal controls in place. The authors also claim that the form of the implemented internal controls depends on the costs of its implementation, as well as on other factors, such as: workforce, workforce motivation and willingness to establish control mechanism irrespective of the type of enterprises. However, if the objective is to have benefits from the implementation of internal controls, then it is necessary to focus on planning overall costs of their implementation and which form of internal control to introduce.

The authors point out that they completed a representative research and that the results are obtained in a survey that comprised 172 enterprises making approximately $25 \%$ of 691 enterprises founded by the local self-government units in the Republic of Serbia. Recommendations relate to expanding the study within future, similar research activities that could be conducted in other countries of the Western Balkans, as well as in other countries in transition.

\section{References}

Alibegovic, D., Hodzic, S., \& Becic, E. (2018). Limited Fiscal Autonomy of Croatian Large Cities. Lex Localis - Journal of Local Self-Government, 16(1), 107-128. https://doi.org/10.4335/10.4335/16.1.107-128(2018)

Blair, D. (2017). Private company finance and financial reporting: what do we know?: a practitioner's view. Accounting and Business Research, 47(5), 538-539. https://doi.org/10.1080/00014788.2017.1318513

Blankley, A. I., Hurtt, D. N., \& MacGregor, J. E. (2012). Abnormal Audit Fees and Restatements. Journal of Practice \& Theory, 31, 79-96. https://doi.org/10.2308/ajpt-10210

Brezovnik, B., \& Oplotnik, Z. (2003). Fiskalna decentralizacija v Sloveniji: oris stanja, problematika in mednarodna primerjava, Maribor: Institut za lokalno samoupravo in javna narocila.

Coffee, J. (2019). Why do auditors fail? What might work? What won't? Accounting and Business Research, 49:5, 540-561. https://doi.org/10.1080/00014788.2019.1611715

Corona, C., Nan, L., \& Zhang, G. (2019). Banks' Asset Reporting Frequency and Capital Regulation: An Analysis of Discretionary Use of Fair-Value Accounting. The Accounting Review, 94(2), 157-178. https://doi.org/10.2308/accr$\underline{52209}$

Chen, H., Wang, D., \& Zhou, N. (2017). A Comprehensive and Quantitative Internal Control Index: Construction, Validation, and Impact. Review of Quantitative Finance and Accounting, 49, 337-377. https://doi.org/ 10.1007/s11156-016-0593-x

Chen, R. (2019). Internal Control Audit Fee and Internal Control Audit Quality-Evidence from Integrated Audits. Open Journal of Business and Management, 7, 292-311. http://www.scirp.org/journal/ojbm; https://doi.org/ 10.4236/ojbm.2019.71020

Cheng, M., Dhaliwal, D., \& Zhang, Y. (2013). Does Investment Efficiency Improve after the Disclosure of Material Weaknesses in Internal Control over Financial Reporting?. Journal of Accounting and Economics, 56, 1-18. https://doi.org/10.1016/j.jacceco.2013.03.001

Davis, J., \& Nicholson-Crotty, S. (2016). Partisanship and tax competition in the American states. Journal of Public Policy, 36(3), 437-456. https://doi.org/10.1017/S0143814X15000136

Drazic-Lutilsky, I., Vasicek, V., \& Vasicek, D. (2012). Planiranje i kontrola troskova u Hrvatskom Javnom Sektoru. Economic Research-Ekonomska Istrazivanja, 25(2), 413-434. https://doi.org/10.1080/1331677X.2012.11517515

Durocher, S., \& Gendron, Y. (2014). Epistemic commitment and cognitive disunity toward fair-value accounting. Accounting and Business Research, 44(6), 630-655. https://doi.org/10.1080/00014788.2014.938012

Ege, S. (2015). Does internal audit function quality deter management misconduct?. The Accounting Review, 90(2), $495-527$. https://doi.org/10.2308/accr-50871

Fatima, A., Abbas, A., Ming, W., Hosseini, S., \& Zhu, D. (2019). Internal and External Factors of Plagiarism: Evidence from Chinese Public Sector Universities. Accountability in Research, 26(1), 1-16. https://doi.org/10.1080/08989621 .2018 .1552834

Horton, J., Macve, R., \& Serafeim, G. (2011). Deprival value' vs. fair value measurement for contract liabilities: how to resolve the 'revenue recognition' conundrum?. Accounting and Business Research, 41(5), 491-514. https://doi.org/ $\underline{10.1080 / 00014788.2011 .603206}$

Izza, M. (2019). 'Why do auditors fail? What might work? What won't?': a practitioner view. Accounting and Business Research, 49(5), 562-564. https://doi.org/10.1080/00014788.2019.1611717 
Milan Radovic, Jelena Vitomir, Slobodan Popovic. Impact of Internal Control in Enterprises Founded by Local ...

Jingwen, N. (2017). When Internal Control Meets Internal Audit: Conflict or Combine?-Based on the Case Analysis of CIMC. Open Journal of Accounting, 6, 43-51. http://www.scirp.org/journal/ojacct. https://doi.org/ 10.4236/ojacct.2017.62004

Lee, E. (2016). CEO Overconfidence and the Effectiveness of Internal Control over Financial Reporting. The journal of applied business research, 32, 81-100. https://doi.org/10.19030/jabr.v32i1.9525

Lewis, C., \& Young, S. (2019). Fad or future? Automated analysis of financial text and its implications for corporate reporting. Accounting and Business Research, 49(5), 587-615. https://doi.org/10.1080/00014788.2019.1611730

Liang, L., \& Riedl, E. (2014). The Effect of Fair Value versus Historical Cost Reporting Model on Analyst Forecast Accuracy. The Accounting Review, 89(3), 1151-1177. https://doi.org/10.2308/accr-50687

Liu, Y. (2010). The Study of the Application Status of Fair Value Accounting in China. International Journal of Business and Management, 5(9), 155-158. https://doi.org/10.5539/ijbm.v5n9p155

Kukovic, S., Hacek, M., \& Bukovnik, A. (2016). The Issue of Local Autonomy in the Slovenian Local Government System. Lex Localis - Journal of Local Self-Government, 14(3), 303-320. https://doi.org/10.4335/14.3.303-320(2016)

Malone, L., Tarca, A., \& Wee, M. (2016). IFRS non-GAAP earnings disclosures and fair value measurement. Accounting \& Finance, 56(1), 59-97. https://doi.org/10.1111/acfi.12204

Majstorovic, A., Popovic, S., \& Volf, D. (2015). Teorija i politika bilansa, drugo izmenjeno i dopunjeno izdanje, Novi Sad: Feljton.

Marston, C., \& Shrives, P. (1991). The use of disclosure indices in accounting research: A review article. The British Accounting Review, 23(3), 195-210. https://doi.org/10.1016/0890-8389(91)90080-L

Mengmeng, L. (2015). Enterprise Internal control and accounting information quality. Journal of financial risk management, 6, 16-26. https://doi.org/10.4236/jfrm.2017.61002

Mijic, R., \& Popovic, S. (2016). Finansijsko Racunovodstvo, Banja Luka: City print.

Perry, T., \& Shivdasani, A. (2005). Do Boards Affect Performance? Evidence from Corporate Restructuring. Journal of Business, 8, 231-246. https://doi.org/10.1086/430864

Pernek, F. (2001). Financno pravo in javne finance - splosni del, Maribor: Pravna fakulteta.

Popovic S. (2014). Socio-ekonomski faktori ogranicenja razvoja agrara, Novi Sad: Feljton.

Popovic, S., Majstorovic, A., \& Grubljesic, Z. (2015). Valuation of facilities in use and application of international accounting standards. Actual problems of economics, 3, 379-387. https://eco-science.net/en/downloads/

Popovic, S., Novakovic, S., Duranovic, D., Mijic, R., Grubljesic, Z, Anicic, J., \& Majstorovic, A. (2017). Application of international accounting standard-16 in a public company with predominantly agricultural activities. Economic ResearchEkonomska Istrazivanja, 30(1), 1850-1864. https://doi.org/10.1080/1331677X.2017.1383171

Pridgen, A., \& Wang, K. J. (2012). Audit Committees and Internal Control Quality: Evidence from nonprofit Hospitals Subject to the Single Audit Act. International Journal of Auditing, 16, 165-183. https://doi.org/10.1111/j.1099-1123. 2012.00448.x

Reginato, E., Fadda, I., \& Paglietti, P. (2016). The Influence of Resistance to Change on Public-Sector Reform Implementation: The Case of Italian Municipalities' Internal Control System. International Journal of Public Administration, 39(12), 989999, https://doi.org/10.1080/01900692.2015.1068325

Renyu, H., \& Kaishi, N. (2015). The application of xbrl in enterprises'internal control report. Theoretical Economics Letters, 5, 179-184. https://doi.org/10.4236/tel.2015.52022

Ruhnke, K., \& Schmidt, M. (2014). The audit expectation gap: existence, causes, and the impact of changes. Accounting and Business Research, 44(5), 572-601. https://doi.org/10.1080/00014788.2014.929519

Santos, H., \& Dias, A. (2014). Administrative reforms and performance of local public policies. International Journal of Public Sector Management, 27(6), 462-474. https://doi.org/10.1108/IJPSM-07-2012-0091

Scalera, F. (2016). The Balkan Area Development: Threats and Opportunities for Italian Companies' Investment Strategies. International Journal of Business and Management, 11(10), 37-50. http://hdl.handle.net/11586/171324 https://doi.org/10.5539/ijbm.v11n10p37

Svoboda, P. (2007). Valuation of tangible fixed assets pursuant to the Czech accounting law and international accounting standards, Agric. Econ.-Czech, 53, 446-474. https://doi.org/10.17221/927-AGRICECON

Tett, G. (2019). Financial scandals: a historical overview': a practitioner view. Accounting and Business Research, 49(5), 500502. https://doi.org/10.1080/00014788.2019.1611706 
Toms, S. (2019). Financial scandals: a historical overview. Accounting and Business Research, 49(5), 477-499. https://doi.org/10.1080/00014788.2019.1610591

Topcu, M., \& Serap, C. (2017). Financial development and firm growth in Turkish manufacturing industry: evidence from heterogeneous panel based non-causality test. Economic Research-Ekonomska Istrazivanja, 30(1), 1758-1769. https://doi.org/10.1080/1331677X.2017.1383179

Vranjes, M. (2011). Finansijsko pravo, Beograd: Zavod za udzbenike.

Wang, Q., Huang, D., \& Young, E. (2014). Internal Control Information Disclosure Situation Analysis-Based on Studies of the Shenzhen Stock Exchange from 2008 to 2012. Taxation and Economy, 1, 57-62. http://mall.cnki.net/magazine/ Article/SWYJ201401010.htm

Wang, W. (2016). Exploring the determinants of network effectiveness: The case of neighborhood governance networks in Beijing. Journal of Public Administration Research and Theory, 26(2), 375-388. https://doi.org/ 10.1093/jopart/muv017

Williams, P., \& Rodgers, J. (1995). The Accounting Review and the Production of Accounting Knowledge. Critical Perspectives on Accounting, 6(3), 263-287. https://doi.org/10.1006/cpac.1995.1025

Williams, C. (2010). Principi menadzmenta, Beograd: Data Status.

Wyatt, A. (2004). Accounting professionalism - they just don't get it!. Accounting Horizons, 18(1), 45-53. https://doi.org/ $\underline{10.2308 / \text { acch.2004.18.1.45 }}$

Wynen, J., \& Verhoest, K. (2016). Internal Performance-Based Steering in Public Sector Organizations: Examining the Effect of Organizational Autonomy and External Result Control. Public Performance \& Management Review, 39(3), 535-559. https://doi.org/10.1080/15309576.2015.1137769

\section{Authors' biographies}

Milan Radovic employed as Assistant Professor at the University of East Sarajevo Alekse Santica No. 3, 71420 Pale, Bosnia and Herzegovina, PhD, Department of Management, Department of Financial Management. He has won numerous awards for the best manager in banking (2009-2016). In addition, he won the award for the best manager of "Republika Srpska" (2010-2011), as well as for the best banker in the region (2015-2016), as well as the prestigious Businessman of the Year award given by "Nazvisne Novine" in 2016. He has published more than 35 scientific papers in the field of business management.

Jelena Vitomir employed as Assistant Professor at the University of Megatrend in Belgrade, Bulevar Marsala Tolbuhina No. 811070 New Belgrade, Republic of Serbia, PhD, Department of Management, Department of Financial Management. He is the author of numerous papers (more than 40) in the field of company management, especially in the field of management and management improvement through the use of valid decisions of top management. In addition, he is the author of several notable works on the management of public companies whose founders are local self-government units in the Republic of Serbia.

Slobodan Popovic (correspondent author) employed as Assistant Professor at the Economic Academy, Faculty of Economics and Engineering Management, Department of Finance, Auditing and Accounting, Cvecarska No. 2, 21000 Novi Sad, Republic of Serbia, PhD. He acquired the title of internal auditor of the public sector in the Republic of Serbia. He is the author of numerous scientific papers in the field of finance, accounting, auditing and applied agriculture. He has published more than 100 scientific papers.

The article has been reviewed.

Received in April 2019; accepted in February 2021.

This article is an Open Access article distributed under the terms and conditions of the Creative Commons Attribution 4.0 (CC BY 4.0) License (http://creativecommons.org/licenses/by/4.0/). 